\title{
ANALISIS SWOT POTENSI PENGEMBANGAN TEKNOLOGI ENERGI GENERATOR MAGNETIK DI INDUSTRI BAJA (STUDI KASUS PT XYZ)
}

\author{
Moch.Kuswanto ${ }^{1}$, Abraham Benedict Cahyasusila ${ }^{2}$, Rudy Agus Gemilang Gultom ${ }^{3}$ \\ Industri Pertahanan, Fakultas Teknologi Pertahanan, Universitas Pertahanan RI ${ }^{1,2}$ \\ Teknologi Penginderaan, Fakultas Teknologi Pertahanan, Universitas Pertahanan $\mathrm{RI}^{3}$
}

Email : $\underline{\text { kus12.2021@gmail.com }}^{1}, \underline{\text { abraham.benedict_ti2012@yahoo.com }}^{2}, \underline{\text { rudygultom67@gmail.com }}^{3}$

\begin{abstract}
Abstrak
Industri baja tergolong dalam kategori industri yang padat energi. Namun permasalahan efisiensi penggunaan energi adalah salah satu permasalahan utama yang dihadapi oleh industri baja nasional. Inefisiensi pemakaian energi akan sangat merugikan bagi industri baja karena terkait dengan jumlah produksi yang dihasilkan serta keuntungan agregat industri. PT XYZ yang merupakan perusahaan baja terpadu di Indonesia mempertimbangkan melakukan efisiensi energi guna menekan biaya produksi dengan kapasitas produksi baja minimal sama dengan kapasitas produksi sebelumnya atau bahkan meningkatkannya. Tujuan penelitian ini untuk mengetahui potensi penggunaan energi generator magnet sebagai sumber energi alternatif yang dapat digunakan di PT XYZ. Metode yang digunakan yaitu metode kualitatif deskriptif dan analisis data dilakukan menggunakan analisis SWOT. Hasil penelitian menyimpulkan bahwa energi listrik dari generator magnet memiliki potensi untuk digunakan sebagai sumber alternatif energi baru terbarukan dan strategi yang dapat digunakan oleh PT XYZ adalah strategi SO (bersifat agresif) yakni dengan mengoptimalkan kinerja divisi Energy Control Center, melakukan upaya pembaruan teknologi diberbagai lini produksi dan terus melaksanakan penelitian dan pengembangan generator magnet sebagai energi alternatif yang baru.
\end{abstract}

Kata Kunci: Energi Generator Magnetik, Industri Baja Nasional, Analisis SWOT

\section{PENDAHULUAN}

Berdasarkan Undang-Undang Nomor 3 tahun 2002, penyelenggaraan pertahanan negara dilakukan untuk mempertahankan kedaulatan negara, keutuhan wilayah Negara Kesatuan Republik Indonesia (NKRI), serta keselamatan bangsa dari berbagai ancaman dan gangguan yang berasal dari dalam maupun luar negeri demi keutuhan bangsa dan negara. Sistem pertahanan negara Indonesia disusun dalam suatu sistem bersifat semesta yang melibatkan berbagai aspek di dalam negara yaitu seluruh warga negara, wilayah negara, serta seluruh sumber daya nasional yang ada dan telah dipersiapkan oleh pemerintah untuk diselenggarakan secara total, terpadu, terarah dan berkelanjutan dalam menjaga kedaulatan negara, keutuhan wilayah, serta keselamatan bangsa dari berbagai ancaman. Oleh karena itu untuk mecukupi kebutuhan pertahanan negara diperlukan membangun industri pertahanan yang kuat dan mandiri. Dalam upaya membangun industri pertahanan yang kuat dan mandiri tersebut diperlukan industri baja nasional yang mampu memproduksi baja berkualitas tinggi dengan biaya produksi baja yang kompetitif.

Ketersediaan sumber daya bahan baku industri baja yang melimpah menjadi salah satu daya dukung Indonesia untuk mencapai kemandirian industri baja. Data Kemenperin tahun 2014 menunjukkan bahwa Indonesia memiliki cadangan bahan baku industri baja yang melimpah yaitu 4,7 miliar ton sumber daya dan 329,5 juta ton cadangan. Jumlah sumber cadangan bahan baku tersebut tersebar di berbagai pulau-pulau Indonesia yaitu Sumatera, Jawa, Kalimantan, Sulawesi, Nusa Tenggara, Maluku dan Papua (Kemenperin, 2014). Kekayaan ini merupakan peluang besar dalam menunjang keberlangsungan industri baja nasional. Akan tetapi, ketersediaan hasil produksi baja belum selaras dengan kapasitas maupun konsumsi industri baja perkapita Indonesia. Tingkat konsumsi baja perkapita Indonesia masih paling rendah apabila dibandingkan dengan negara-negara ASEAN (World Steel Statistical Yearbook, 2019). Kondisi kapasitas industri baja nasional belum 
mampu memenuhi kebutuhan domestik sesuai dengan tingkat konsumsi dan produksi baja nasional. Kapasitas produksi tersebut juga mempengaruhi tingkatan harga produk baja yang dipasarkan. Kondisi ini menjadi peluang bagi produk baja impor mengisi kesenjangan tersebut. Lemahnya daya saing harga ini bukan hanya sekedar mengakibatkan terbaginya porsi pasar domestik namun juga mengakibatkan tertekannya demand besi baja domestik.

Pemenuhan kapasitas produksi industri baja nasional tidak terlepas dari kebutuhan energi. Energi menjadi kebutuhan yang pokok dalam pembangunan industri, oleh karena itu kondisi penyediaan energi untuk mendorong pertumbuhan industri menjadi hal yang sangat penting. Dari data historis pada beberapa industri yang berhasil dikumpulkan oleh Kementerian ESDM, diperoleh informasi bahwa saat ini intensitas energi industri baja di Indonesia sebesar $900 \mathrm{kWh}$ per Ton (BPPT, 2013, p.50). Artinya, untuk menghasilkan 1 (satu) Ton baja di Indonesia membutuhkan energi sebesar $900 \mathrm{kWh}$. Apabila dibandingkan dengan India dan Jepang, maka angka intensitas ini lebih tinggi, dimana intensitas energi industri baja di India hanya sebesar $600 \mathrm{kWh} /$ ton dan Jepang $350 \mathrm{kWh} / \mathrm{ton}$. Dari sumber data BPPT ini maka dapat disimpulkan bahwa penggunaan energi dalam proses pembuatan baja di Indonesia belum seefisien kedua negara yang diperbandingkan tersebut. Intensitas energi yang masih tinggi merupakan salah satu permasalahan yang dihadapi oleh industri baja. Inefisiensi pemakaian energi akan sangat merugikan bagi industri baja karena terkait dengan jumlah produksi yang dihasilkan serta keuntungan agregat industri. Dampak yang lebih besar lagi adalah inefisiensi energi dalam skala massif dan berkepanjangan dapat menyebabkan inefisiensi ekonomi nasional melalui alokasi sumber daya yang tidak optimal.

Menjawab tantangan permasalahan negara tersebut, salah satu perusahaan yang bergerak dibidang industri baja dan terpadu yaitu PT XYZ mempertimbangkan melakukan efisiensi guna menunjang peningkatan kapasitas produksi baja. Saat ini PT XYZ menggunakan pembangkit energi milik perusahaan penyedia energi yang berbahan bakar Gas (Liquid Natural Gas) sebesar 102Mw yang beroprasi 24 jam dalam setahun dan sebagian energi yang lain berasal dari pasokan listrik PLN sebesar $146 \mathrm{Mw}$. Berdasarkan kondisi tersebut PT XYZ mempertimbangkan untuk mengganti bahan bakar pembangkit listrik perusahaan agar dapat diperoleh penghematan biaya listrik.

Kondisi ini kemudian menarik perhatian peneliti untuk meneliti potensi sumber energi alternatif baru yang mampu memberikan kontribusi terhadap peningkatan efisiensi energi di PT XYZ. Salah satu sumber energi alternatif yang dipertimbangkan untuk digunakan adalah Energi Generator Magnet. Energi generator magnet adalah energi dari alam yang memiliki kemampuan tidak terbatas. Energi generator magnet merupakan pembangkit energi listrik yang memanfaatkan gaya tarik menarik dan tolak menolak susunan magnet permanen yang memutar rotor penghasil medan magnet terhadap kumparan sehingga menghasilkan gaya gerak listrik (GGL) yang dapat digunakan sebagai sumber energi dalam aktivitas produksi baja di PT XYZ. Prayogo (2020) menyebutkan bahwa energi generator magnet memiliki kelebihan dapat digunakan dalam jangka waktu panjang, lebih praktis dan efisien dibanding sumber energi lainnya.

\section{METODE PENELITIAN}

Penelitian ini menggunakan pendekatan kualitatif yaitu suatu proses penelitian dan pemahaman yang berdasarkan pada metodologi yang menyelidiki suatu fenomena sosial dan masalah manusia (Utama, 2012: 119). Metode penelitian yang digunakan kualitatif deskriptif yaitu suatu penelitian yang digunakan untuk mengetahui nilai variabel mandiri, baik satu variabel atau lebih (independen) tanpa membuat perbandingan atau menghubungkan dengan variabel lain (Sugiyono, 2017: 86).

Lokus penelitian ini dilaksanakan di PT XYZ, Jawa Barat. Waktu penelitian diadakan pada bulan September-Desember 2021. Narasumber dalam penelitian ini berasal dari Divisi Riset dan Teknologi PT XYZ. Penentuan narasumber dalam penelitian ini menggunakan teknik puprosive sampling yaitu teknik penentuan narasumber berdasarkan kriteria atau pertimbangan tertentu yang memiliki hubungan dominan yang mengarah pada keberhasilan pencapaian tujuan penelitian (Sugiyono, 2017). Teknik pengumpulan data dilakukan menggunakan teknik pengumpulan data primer melalui observasi dan wawancara, serta teknik pengumpulan data sekunder melalui studi literatur. Teknik pengolahan data yang digunakan adalah analisis SWOT. Analisis SWOT ini dapat menggambarkan secara jelas bagaimana peluang dan ancaman eksternal yang dihadapi perusahaan sehingga dapat disesuaikan dengan kekuatan dan kelemahan yang dimilikinya (Rangkuti, 2013). 


\section{HASIL PENELITIAN DAN PEMBAHASAN}

\section{Porsi Konsumsi Energi Pada Proses Produksi Baja PT XYZ}

Industri baja termasuk dalam kategori industri pengguna energi di atas 6.000 TOE (setara ton minyak) sehingga termasuk dalam industri yang padat energi. Distribusi pemakaian energi dalam industri baja dapat dilihat pada Gambar 1. Dalam gambar ditunjukkan bahwa Industri baja menggunakan energi untuk proses peleburan scrap, heat treatment dan metal forming serta proses finishing (BPPT, 2013, p.43).

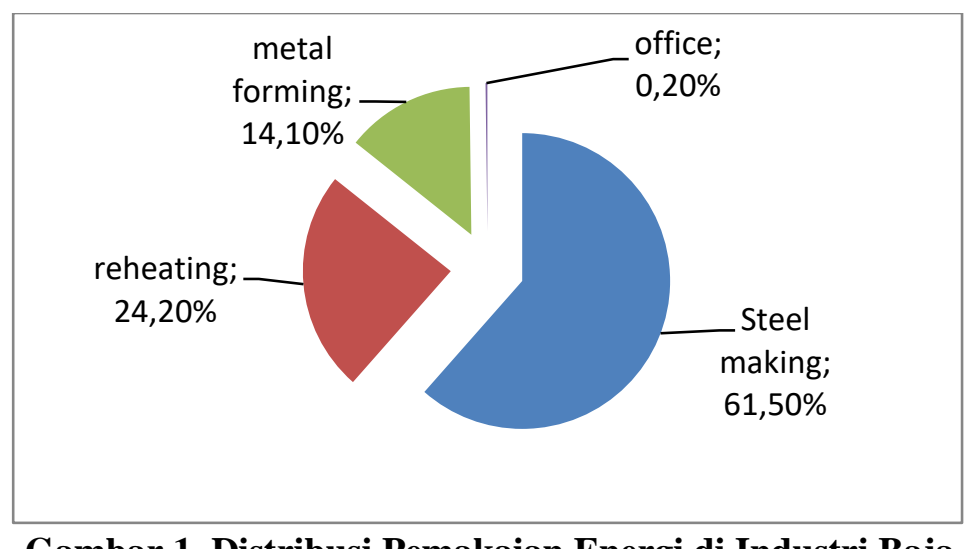

\section{Gambar 1. Distribusi Pemakaian Energi di Industri Baja} (Sumber: BPPT, 2013)

Pada penelitian ini peneliti akan menganalisis potensi dan strategi pengembangan energi generator magnetik pada proses steel making yang dilakukan pada unit Hot Strip Mill (HSM), dikarenakan penggunaan berbagai jenis energi terbesar pada alur produksi produk baja di PT XYZ terdapat pada proses steel making. Pada Gambar 2 ditunjukkan bahwa penggunaan energi yang terbesar adalah Hot Strip Mill yaitu penggunaan gas alam sebesar $88 \%$ dan penggunaan listrik sebesar $58 \%$ dari keseluruhan proses produksi baja (PT XYZ, 2018).
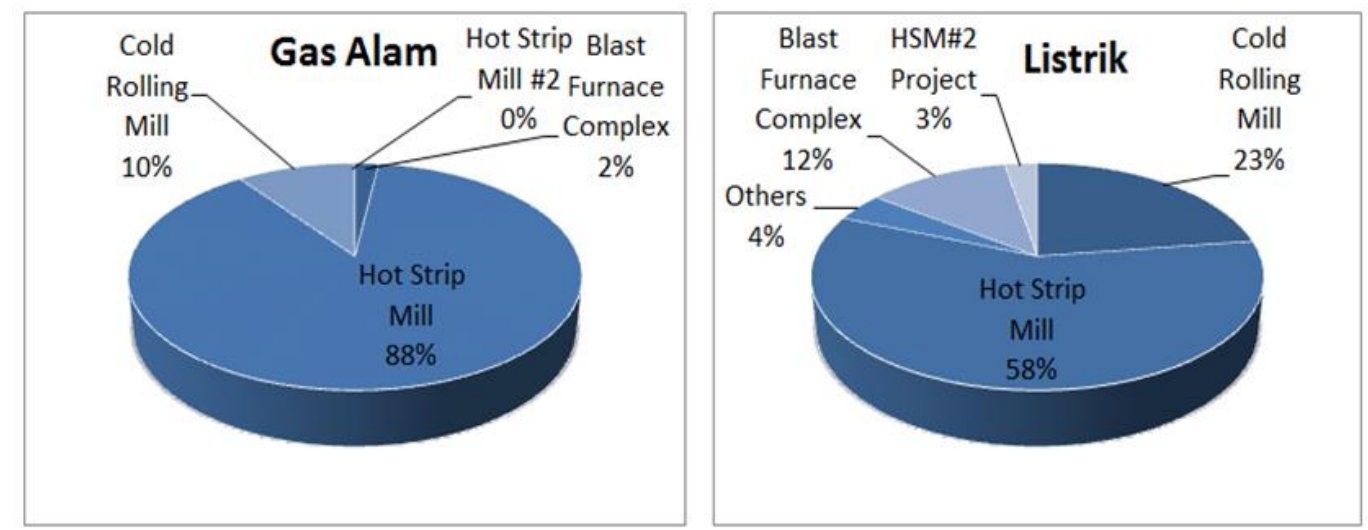

\section{Gambar 2 Porsi Konsumsi Energi Pada Keseluruhan \\ Proses Produksi Baja PT XYZ \\ (Sumber: PT XYZ, 2018)}

Porsi konsumsi energi pada proses HSM ditunjukkan pada gambar 3. Dalam gambar tersebut ditunjukkan bahwa porsi konsumsi energi pada proses HSM adalah 30\% energi listrik dan $70 \%$ gas alam. Konsumsi energi sebesar 30\% yang berasal dari energi listrik digunakan untuk menggerakkan mesin-mesin produksi yaitu sizing press, roughing mill, finishing mill, laminar colling, down coiler hingga menjadi baja gulungan (HRC). Sedangkan konsumsi energi sebesar $70 \%$ berasal dari gas alam digunakan untuk proses reheating. 


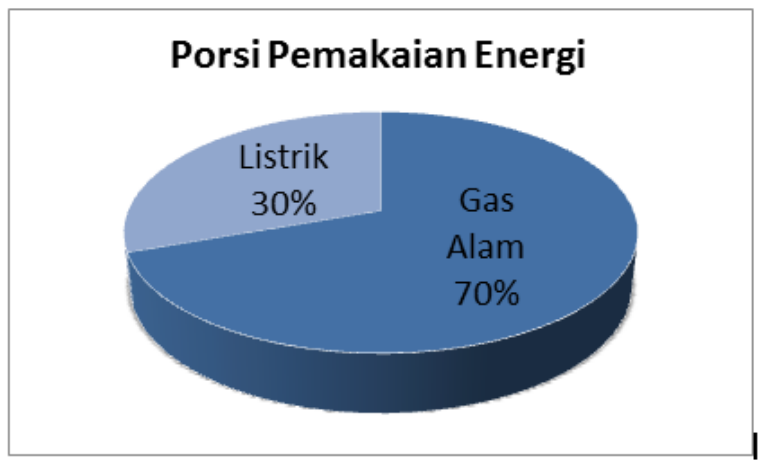

\section{Gambar 3 Porsi Konsumsi Energi Listrik-Gas Alam HSM}

(Sumber: PT XYZ, 2018)

\section{Analisis SWOT Potensi Pengembangan Energi Generator Magnetik di PT XYZ}

Sebelum melakukan penerapan energi generator magnetik di PT XYZ maka diperlukan analisa kelayakan baik dari skala teknis dan bisnis yang lebih mendetail. Oleh karena itu untuk melihat potensi dan strategi pengembangan energi generator magnetik di PT XYZ perlu dilakukan identifikasi untuk faktor internal dan eksternal perusahaan. Berikut adalah evaluasi faktor internal meliputi kekuatan (strength) dan kelemahan (weakness) dan evaluasi faktor eksternal yang meliputi peluang (opportunity) dan ancaman (treath) mengenai potensi pengembangan energi generator magnetik di PT XYZ yang penulis dapatkan setelah melakukan wawancara langsung dengan pihak-pihak yang terkait dengan penelitian ini.

\section{Evaluasi Faktor Internal (IFE)}

a. Kekuatan (Strength)

1) Adanya kontrak kerjasama dengan perusahaan penyedia energi gas sehingga kebutuhan biaya energi dapat tercukupi dengan baik.

2) Produksi berjalan sesuai dengan kebutuhan dan permintaan.

3) Nilai jual produk yang tinggi

4) Kompetensi SDM yang sudah sesuai.

b. Kelemahan (Weakness)

1) Biaya energi listrik dan gas alam yang mahal dan jumlahnya terbatas.

2) Terkadang ditemukan kendala yang menghambat produksi.

3) Tingkat konsumsi baja masyarakat Indonesia masih cukup rendah dan tidak sebanding dengan jumlah kelimpahan sumber daya mineralnya,

4) Diperlukan pelatihan dan pendidikan terutama dalam proyek riset apabila akan dilakukan pergantian sumber daya energi.

\section{Evaluasi Faktor Eksternal (EFE)}

a. Peluang (Opportunity)

1) Aplikasi energi magnet sebagai sumber energi alternatif turut mendukung kebijakan pemerintah dalam pemanfaatan sumber daya mineral dan emisi rumah kaca.

2) Energi magnet merupakan sumber energi alternatif dengan cost rendah.

3) Energi magnet merupakan sumber energi zero waste

4) Energi magnet memiliki teknologi yang tinggi dan terintegrasi dalam sistem termutakhir

b. Ancaman (Threat)

1) Penelitian dan pengembangan energi magnet memerlukan perizinan dan lolos penilaian dari pemerintah yang membutuhkan waktu cukup lama.

2) Diperlukan investasi dana yang besar untuk penelitian, pengembangan dan pengadaan alat

3) Kemampuan SDM yang masih terbatas

4) Diperlukan pembaharuan teknologi dikarenakan energi magnet masih digunakan untuk skala rumah tangga 


\begin{tabular}{|c|c|c|c|}
\hline Evaluasi Faktor Internal & Bobot & Rating & Skor \\
\hline \multicolumn{4}{|l|}{ Kekuatan } \\
\hline $\begin{array}{l}\text { 1. Adanya kontrak kerjasama } \\
\text { dengan perusahaan penyedia } \\
\text { energi }\end{array}$ & 0,12 & 4 & 0,48 \\
\hline $\begin{array}{l}\text { 2. Produksi berjalan } \\
\begin{array}{l}\text { dengan } \\
\text { permintaan. }\end{array}\end{array}$ & 0,14 & 4 & 0,56 \\
\hline 3. Nilai jual produk yang tinggi & 0,14 & 3 & 0,42 \\
\hline $\begin{array}{l}\text { 4. Kompetensi SDM yang sudah } \\
\text { sesuai. }\end{array}$ & 0,11 & 3 & 0,33 \\
\hline Total Skor Kekuatan & $\mathbf{0 , 5 1}$ & & 1,79 \\
\hline \multicolumn{4}{|l|}{ Kelemahan } \\
\hline $\begin{array}{l}\text { 1. Biaya energi listrik dan gas } \\
\text { alam yang mahal dan } \\
\text { jumlahnya terbatas. }\end{array}$ & 0,13 & 2 & 0,26 \\
\hline $\begin{array}{l}\text { 2. Terkadang ditemukan kendala } \\
\text { yang menghambat produksi. }\end{array}$ & 0,1 & 1 & 0,1 \\
\hline $\begin{array}{l}\text { 3. Diperlukan pelatihan dan } \\
\text { pendidikan dalam proyek riset } \\
\text { apabila akan dilakukan } \\
\text { pergantian sumber daya energi. }\end{array}$ & 0,13 & 2 & 0,26 \\
\hline $\begin{array}{l}\text { 4. Tingkat konsumsi } r \text { baja } \\
\text { masyarakat Indonesia masih } \\
\text { cukup rendah dan tidak } \\
\text { sebanding dengan jumlah } \\
\text { kelimpahan sumber } \\
\text { mineralnya, daya }\end{array}$ & 0,13 & 2 & 0,26 \\
\hline Total Skor Kelemahan & $\mathbf{0 , 4 9}$ & & $\mathbf{0 , 8 8}$ \\
\hline Total Kekuatan + Kelemahan & 1 & & 2,67 \\
\hline
\end{tabular}

Sumber: Diolah Peneliti

Tabel 2. Matrik EFE

\begin{tabular}{|c|c|c|c|}
\hline Evaluasi Faktor Eksternal & Bobot & Rating & Skor \\
\hline \multicolumn{4}{|l|}{ Peluang } \\
\hline $\begin{array}{l}\text { 1. Sumber energi alternatif yang } \\
\text { mendukung } \\
\text { pemerintah } \\
\text { pemanfaatan } \\
\text { dalam } \\
\text { mineral dan emisi rumah } \\
\text { kaca. }\end{array}$ & 0,12 & 4 & 0,48 \\
\hline $\begin{array}{l}\text { 2. Energi magnet merupakan } \\
\text { sumber energi alternatif } \\
\text { dengan cost rendah. }\end{array}$ & 0,11 & 3 & 0,33 \\
\hline $\begin{array}{l}\text { 3. Energi magnet merupakan } \\
\text { sumber energi zero waste }\end{array}$ & 0,12 & 3 & 0,36 \\
\hline $\begin{array}{l}\text { 4. Energi magnet memiliki } \\
\text { teknologi yang tinggi dan } \\
\text { terintegrasi dalam sistem } \\
\text { termutakhir }\end{array}$ & 0,13 & 2 & 0,26 \\
\hline Total Skor Peluang & 0,48 & & 1,43 \\
\hline \multicolumn{4}{|l|}{ Ancaman } \\
\hline
\end{tabular}


energi magnet memerlukan

perizinan dan lolos penilaian

dari pemerintah yang

membutuhkan waktu cukup

lama.

2. Diperlukan investasi dana yang besar untuk penelitian,

$\begin{array}{lll}0,14 & 2 & 0,28\end{array}$
pengembangan dan pengadaan alat

3. Kemampuan SDM yang masih terbatas

4. Diperlukan pembaharuan teknologi dikarenakan energi magnet masih digunakan untuk skala rumah tangga

\begin{tabular}{lcc}
\hline Total Skor Ancaman & $\mathbf{0 , 5 2}$ & 1,31 \\
\hline Total Peluang + Ancaman & 1 & 2,74 \\
\hline
\end{tabular}

Sumber: Diolah Peneliti

Berdasarkan tabel matrik IFE dan matrik EFE didapatkan hasil perbandingan analisis internal dengan analisis eksternal pada PT XYZ adalah sebagai berikut:

$\mathrm{x}=$ Total Skor Kekuatan (strength) - Total Skor Kelemahan (weakness)

$\mathrm{y}=$ Total Skor Peluang (opportunity) - Total Skor Ancaman (treath)

Dimana $\mathbf{x}=\mathbf{1 , 7 9}-\mathbf{0 , 8 8}=\mathbf{0 , 9 1}$ dan $\mathbf{y}=\mathbf{1 , 4 3}-\mathbf{1 , 3 1}=\mathbf{0 , 1 2}$. Selanjutnya nilai $\mathrm{x}$ dan $\mathrm{y}$ tersebut diasumsikan sebagai titik koordinat yang diplot ke dalam diagram cartesius SWOT sebagaimana ditunjukkan pada Gambar 4. Diagram Cartesius SWOT.

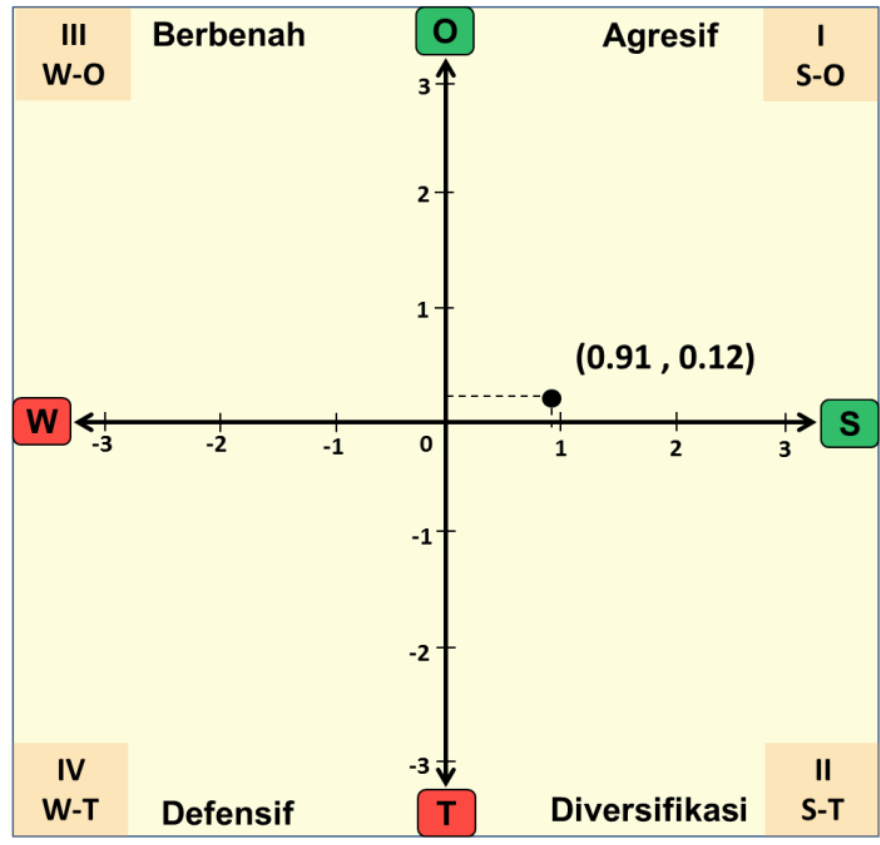

Gambar 4. Diagram Cartesius SWOT

(Sumber: Diolah Peneliti)

Berdasarkan gambar di atas didapatkan hasil bahwa PT XYZ berada pada kuadran 1 yaitu strategi agresif (Strength Opportunity), maka strategi yang dapat digunakan untuk memaksimalkan potensi pengembangan energi generator magnet di PT XYZ perusahaan dituntut berfokus untuk: 1) Melaksanakan efisiensi produksi dengan mengganti sumber energi ke energi alternatif baru 
terbarukan, seperti generator magnet; 2) Mengoptimalkan kinerja divisi Energy Control Center yang dapat memonitor dan mengevaluasi penggunaan energi di PT XYZ; 3) Melakukan upaya pembaruan teknologi diberbagai lini produksi; 4) Melaksanakan penelitian dan pengembangan mengenai potensi setiap sumber daya energi terbarukan secara lengkap, salah satunya mengenai penggunaan generator magnet.

\section{KESIMPULAN}

Setelah melakukan analisis SWOT terhadap potensi pengembangan energi generator magnet di PT XYZ, maka dapat disimpulkan bahwa energi generator magnet memiliki potensi untuk digunakan sebagai sumber alternatif energi baru terbarukan, maka PT XYZ diharapkan dapat menggencarkan penelitian dan pengembangan generator magnet sebagai energi alternatif baru. Penggunaan energi generator magnet dapat dimulai dengan skala kecil terlebih dahulu seperti untuk pemenuhan energi listrik perkantoran yang kemudian dikembangkan menjadi sumber energi alternatif dalam proses produksi baja di PT XYZ. 


\section{DAFTAR PUSTAKA}

Badan Pengkajian dan Penerapan Teknologi (2013). Perencanaan Efisiensi Dan Elastisitas Energi 2013: Roadmap Teknologi Efisiensi Energi Pada Industri Baja. Tangerang Selatan: Balai Besar Teknologi Energi.

Joko, S. D., dan Tegor (2019). National security of investment climate: a case study in the South Sulawesi region of indonesia. Russian Journal of Agricultural and Socio-Economic Sciences, 85(1).

Kementerian Perindustrian. (2014). Profil Industri Baja. Jakarta

Prayogo, L. G., Dahlan, D., \& Maulana, E. (2020). Analisis energi Yang Dihasilkan Pada Pembangkit Listrik Tenaga Magnet Dengan Konsep V-Gate. In Prosiding Seminar Rekayasa Teknologi (SemResTek) (pp. KE11-KE21).

PT XYZ (2018). General Overview PT PT XYZ.

Rangkuti, F. (2013). Teknik Membedah Kasus Bisnis Analisis SWOT Cara, Perhitungan Bobot, Rating dan OCAI. Jakarta: Gramedia Pustaka Utama

Sugiyono. 2017. Metode Penelitian Pendidikan Pendekatan Kuantitatif, Kualitatif dan R\&D. Bandung: Alfabeta

Tegor., dan Umar, Husein. (2017). Compensation analysis in relationship moderation between transformational leadership style and work environment on the employee performance. Russian Journal of Agricultural and Socio-Economic Sciences, 71(11).

Tegor, T., Yusmalina, Y., \& Haqiqi, F. (2021). PENERAPAN STANDAR AKUNTANSI DAN KUALITAS APARATUR TERHADAP LAPORAN KEUANGAN PEMERINTAH DAERAH (Studi Kasus pada Dinas Pekerjaan Umum dan Penataan Ruang Kabupaten Karimun). JURNAL CAFETARIA, 2(1), 13-24.

Utama. I Gusti Bagus Rai. 2012. Metodologi Penelitian Pariwisata dan Perhotelan, CV Andi Offset: Yogyakarta

Undang-Undang Nomor 3 Tahun 2002 Tentang Pertahanan Negara

World Steel. 2019. World Steel Statistical Yearbook 2019. Diakses melalui www.worldsteel.org

Yusmalina, Y., Tegor, T., Haqiqi, F., Rosady, R. E., \& Azura, N. (2021). Comparative Analysis of Staretegi Traditional Market and Modern Markets of Consumer Valuation. International Journal of Multicultural and Multireligious Understanding, 8(11), 18-25. 